The concluding communication, entitled "The Use of Ana. logue Computers for Studies in Ground-water Hydrology", was contributed by Mr. H. E. Skibitzke, who is mathematician at Water Resources Division, U.S. Geological Survey, Phoenix, Arizona. The Division has applied computer techniques to many of the problems encountered in its operations.

Digital computers are used in the surface-water measurement programme, and in soil-moisture and evaporation studies. Water-level data in rivers, too, have been collected on digital tapes ; such records can be processed quickly, without elaborate programming. In addition, an analogue computing programme has been developed since 1954, when it was originally applied to groundwater systems. About three years ago an operational analogue model unit was established, to apply geological and hydrological information-already available from data-collecting programmes - to a community's water problems. The ground-water computing systems are of the direct analogue type, using the relationship between Darcy's law and Maxwell equations. The analogies between electrical resistance and permeability times a distance, also between electrical capacitance and storage coefficient times a volume, provide the basis. Models are constructed, similar to large-scale maps, which contain, in scale, a physical description of the relating function.

Mr. Skibitzke showed, by mathematical reasoning, how to derive an expression for the rate of release of liquid from a given volume as hydraulic head is changing with time ; this equation is then used in determining an elec. trical analogy, using an expression for the electrical current flowing into a junction of an electrical network. Electrical analogies are then given for head, storage coefficient, and permeability. Head is analogous to electrical potential; storage coefficient times the finite volume of the aquifer is diroctly analogous to electrical capacitance; days in the aquifer are proportional to a few microseconds on an oscillograph scroen connectod to the analogue model.

In the model constructed on these analogies, the electrical resistors are made proportional to the hydraulic resistance of the aquifor in directions parallel to the three co-ordinate axes. The directions of the axes are the same for the models. The networks are chosen to represent, in scale, a small element of the aquifer, the centre of an element in the aquifer being represented by the centre of a junction of a resistor network. An electrical capacitor proportional to the storage coefficient is connected from this junction to the ground. By a generalized application of mathematical equations given in the communication, varia tions in hydraulic permeability can be accounted for by varying the electrical resistance. Boundary-condition problems can be studied by arranging for an electrical current flow-system, that is quantitatively proportional to the hydraulic flow system, to pass into and out of the model. Mr. Skibitzke discussed also the importance of choice of scale as between the actual aquifer and the electrical simulation of conditions in the model. The quantities of electrical current put into the model can be chosen so that space, time, quantity, and head will appear with a known figure of proportionality. The effects of recharge from rainfall or rivers and other kindred conditions can be studied in their variations over very long periods of time. Quantitative data are 'removed' from the model by an oscilloscope which indicates, in microseconds, the change in eloctrical potential, as a function of time, at its input terminals.

After describing the practical operation of the computer, Mr. Skibitzko referred to future developments. Almost any conceivable hydrological system can be studied by computer methods, though in some cases the cost would be prohibitive. Present research work is aimed at reducing the constructional cost of models and at simplifying the electronic linkages that are needed to describe boundary conditions. Finally, Mr. Skibitzke refered to some highly complex hydrological conditions, not amenable to rigorous mathematical analysis, in which computations of groundwater flow parameters have led to greatly increased understanding of what is actually occurring in aquifers. In particular, he mentioned the effect of the ovaporative process that seems to occur ovor all shallow water-tables. In fields such as this, developments in analogue computing have helped substantially in both the theoretioal and the practical analysis of a hydrological problem. A film was shown illustrating the analogue installation at Phoenix, Arizona, on which Mr. Skibitzke and his colleagues had been working.
W. O. SKEAT

\title{
PROTEINS AND CRYSTALLOGRAPHY
}

$\mathrm{T}$ HE award of tho 1962 Nobel Prizes for Medicine and Chemistry to Dr. F. H. C. Crick, Prof. W. Watson and Prof. M. H. F. Wilkins, for their work on the structuro of nucleic acids, and to Dr. J. C. Kendrew and Dr. M. F. Perutz, for their analyses of protein structuros, has directed attention to the outstandingly fruitful contribution made by X-ray crystallography to our knowledge of biologically important molecules. The international symposium on "Protein Structure and Crystallography", held at the University of Madras during January 14-18, was, therefore, particularly well timed. In effect there were two symposia, with sessions hold on alternato days, at which recent work on protein structures and the developments of X-ray erystallography were discussed. But the two subjects inevitably overlappod in the discussions of the X-ray mothod appliod to molecular struc. ture analysis at which exponents of different techniques were brought logether and hence helped to assoss the significance of each other's results.

The symposium was organized by Prof. G. N. Ramachandran and his staff, with the support of the University of Madras, the Indian Council of Scientific and Industrinl Research, the Indien University Grant Commission and other Government and private ageneies. Sir A. L. Mudaliar, vice-chancellor of the University, welcomed the dolegates and Sir C. V. Raman gave an inaugural address on "Crystal Structure and Crystal Behaviour". The sessions were opened by Prof. M. S. Thacker.

The President of the symposium was Sir Lawrence Bragg (United Kingdom), whose address was read, in his absence through illness, by Prof. Ramæchandran. He describod the devolopment of $\mathrm{X}$-ray structure analysis as applied to complex molecules, mentioning the PaulingCorey $\alpha$-helix, the Watson-Crick double helix for deoxyribonucloic acid (DNA) and the Ramachandran triple helix for collagen as the main achievements of the indirect approach, and the analyses of vitamin $B_{12}$ and of the proteins hrmoglobin and myglobin as triumphs of the single-crystal method.

The X-ray analysis of globular protein structures was described in more detail by Prof. D. Harker (United States), who announced the latest results of his work on ribonuclease, and by Dr. D. C. Phillips (United Kingdom), who outlined tho recent dovolopments of work on hæmoglobin and myoglobin and a number of other proteins, including lysozyme, $\alpha$-chymotrypsin and $\beta$-lactoglobulin. 
The structure of myoglobin is now being studied at atomic resolution and analyses of oxygenated and reduced hæmoglobin are revealing the nature of the oxygenation reaction in detail.

A paper read for Dr. R. W. G. Wyckoff (United States) described the role of electron microscopy in the study of biological molecules, and Prof. M. N. Das Gupta (India) showed electron micrographs of individual hæmoglobin molecules in which traces of the sub-unit structure could be seen. Dr. S. Moore (United States) gave an account of the chemical mothods by means of which the primary structures of proteins, such as ribonuclease, have been determined, and Dr. R. S. V. Sampath Kumar (United States) showed how the structure of the active site in carboxypeptidase has been mapped out by chemical methods. A paper by Prof. T. Weis-Fogh (Denmark) dealt with the physical and chemical properties of resilin, a rubber-like protein with interesting cross-linkages found in the wings of insects, and Prof. R. V. Seshaiya, (India) described work on the amino-acid composition of iehthylepedin, a protein found in fish scales resembling collagen but which has an appreciable cystine content. Dr. J. Segal (East Germany) described his model of protein structures.

An important group of papers dealt with the structure of collagen and related proteins and polypeptides. Prof. G. N. Ramachandran (India) described the latest developments of the X-ray work on collagen itself. Refinement of the original triple helix structure has led to a structure closely consistent with the X-rsy diffraction, infra-red absorption and chemical data. Prof. M. Kakudo (Japan) discussed the single-crystal X-ray analysis of a glycyl-L-propyl-L-leucyl glycine derivative, a tetrapeptide related to collagen. Dr. W. Traub (Israel) described the structure of poly-L-proline-I, which has been found to have the cis type of configuration, and Prof. E. Katchalski (Israel) described the synthesis and properties of some copolymers related to poly-L-proline, which has been shown from hydrodynamic and optical studies to exist in two forms in solution in suitable solvents just as it does in the solid state. Dr. N. S. Andreeva (U.S.S.R.) described structural studies of poly(gly-Lpro-L-hypro-), which closely resembles collagen. Some aspects of collagen biosynthesis were dealt with by Prof. M. Chvapil (Czechoslovakia), and the results and interpretation of electron microscope studies of tropocollagen were described and discussed by Prof. A. J. Hodge (United States). Dr. S. M. Bose (India) gave a paper on the nature of the linkages between the carbohydrate moiety and the proteins in skin mucoid.

Other polypeptides and fibrous proteins were discussed by Dr. G. Swanbeck (Sweden), who gave a paper on the molecular structure of $\alpha$-keratin, and by Dr. F. Happey (United Kingdom), who discussed ways in which the structures of polypeptides and proteins can be stabilized. Dr. V. Sasisekharan (India) reported a sterc ochemical study of polypeptide and polysaccharide chains which has indicated the stable configurations.

In a session on optical studies of proteins, Prof. J. T. Edsall (United States) described the use of ultra-violet absorption spectra in the investigations of protein chain configurations; changes in the spectra due to different reagents are perticularly useful for evaluating helical chain content. Dr. E. R. Blout (United States) reviewed recent experimental work on the optical rotatory dispersion of proteins and polypeptides and showed how the helical content and the sense of the helix can be determined by this method. Dr. T. Miyazawa (Japan) discussed the use of infra-red absorption and showed that, by studying the frequencies of absorption bands and their dichroic behaviour, it is possible to identify various configurations of the protein chains.

The topic of protein biosynthesis was introduced by Prof. M. H. F. Wilkins (United Kingdom), who gave an account of his X-ray diffraction studies of nucleic acids.
It has been established that protofibrils of DNA consist of a double helix and transfer RNA has been shown recently to incorporate helices of the same kind. The mechanism of protein synthesis was discussed with reference to the possible structure of the transfer RNA molecules. Prof. S. Ochoa (United States), 1959 Nobel Laureate in Medicine, discussed the use of synthetic polynucleotides in breaking the genetic code, the code connecting the sequence of amino-acids in a protoin with the sequence of nucleotides in the nucleic acid which controls its synthesis. Very recently, some 41 nucleotide triplets have been discovered, each of which appears to govern the incorporation in a protein chain of one of the twenty amino-acids. Finally, in the protein structure sessions, Dr. L. D. Hamilton (United States) gave a paper on "Proteins, Coding and Medicine", which reviewed the occurrence of hereditary diseases due to abnormalities in the nucleic acids giving rise to the synthesis of abnormal proteins. The origins of some forms of anæmia, for example, can now be traced through the detailed structure of the abnormal hæmoglobin, revealed by X-ray and chemical methods, in which one abnormal amino-acid is incorporated, to the single nucleotide change in the parent DNA which is responsible for it.

The sessions on crystallography were opened by Prof. M. J. Buerger (United States), who discussed the interpretation of Patterson syntheses, considered as image functions, for which he has developed an interesting image algebra. This problem was also considered in $\mathrm{kt}$ paper by S. Raman and W. N. Lipscomb (United States). who have used Buerger's sum and minimum functions, and by D. McLachlan, jun. (United States), who has devised optical analogue computers for use in the solution of Patterson syntheses and in direct methods of structure analysis. This central problem of structure analysis, the determination of structures directly from the diffraction data, was also discussed by other speakers. Prof. Ramachandran deseribed the development in Madras of methods for completing the determination of a structure when part of it is already known. A paper by Prof. W Hoppe (West Germany) and his colleagues dealt with two new direct methods one of which, based on Sayre's method, is useful for obtaining the signs of additional structure factors when those of a smaller set are already known. Dr. R. Srinivasan (India) described his work with Drs. W. Cochran and P. Tollin (United Kingdom) on the use of an electronic computer, Edsac $I I$, in sign determination, and Prof. I. Nitta (Japan) discussed his statistical method. A further paper by Prof. Ramachandren and his colleagues described some statistical tests for erystal isomorphism.

A second group of papers dealt with the anomalous scattering of $X$-rays and the use of the effect both in structure analysis and in the determination of absolute configuration. They were introduced by a paper from Prof. J. M. Bijooet's laboratory in Holland dealing with the absolute configurations of sodium chlorate and sodium bromate, which are alike in structure and have the same sense for optical rotation but have opposite configurations. Prof. S. Ramaseshan (India) discussed the technical problems involved in recording anomalous dispersion data for structure analysis, and Dr. K. Venkatesen (India) described how he, Dr. D. Dale and Prof. Dorothy Hodgkin (United Kingdom) solved the structure of a vitamin $B_{12}$ derivative by this method. Dr. G. Kartha (United States) described the solution of another structure, barium glucose orthophosphate.

The effects of crystal perfection on X-ray scattering were considered in a number of papers. Prof. G. Borrmann (West Germany) described interference fringes which can be produced in dislocation-free crystals and Prof. L. V. Azaroff (United States) showed how accurate measurements of the Bragg reflexions can be used to reveal the imperfections present in a crystal. Prof. S. Chandrasekhar (India) presented some results obtained by using measurements with polarized $\mathrm{X}$-rays to correct 
for extinction, and R. Parthasarathy (India) described some new measurements of intensities reflected by perfect and imperfect crystals. Prof. M. Renninger (West Germany) described a technique whereby lattice deformations of the order of less than a tenth of a second of arc can be made visible by a double spectrometer device, and Prof. N. Kato (Japan) diseussed the application of the dynamical theory of wave diffraction to the study of slightly distorted crystals. Disorder phenomena were discussed by Prof. H. Jagodzinsky (West Germany), who outlined their general nature and pointed out that a mathematical treatment of disorder in two or three dimensions is difficult to work out. Prof. I. Waller (Sweden) spoke on the influence of crystal vibrations, as affected by impuritios and anharmonicities, on neutron scattering and on the Mossbauer effect. He was followed by Prof. Ajit Ram Verma (India), who presented the results of his investigations on disorder in silicon carbide, and by Prof. A. J. C. Wilson (United Kingdom), who dealt with the measurement of line-broadening in $\mathrm{X}$-ray powder diffractometry.

Electron and neutron diffraction were discussed by Prof. S. Miyake (Japan) and his colleagues, who described an electron diffraction investigation of phthalocyanine and its metal derivatives; by Dr. J. Shankar (India), who reviewed the use of neutron diffraction in the study of hydrogen bonding; and by Dr. P. K. Iyengar (India), who described the powder and single-crystal diffractometers constructed at Trombay, India, for use with neutrons. Instruments for crystallographic studies were also deseribed by Dr. W. A. Wooster (United Kingdom), who has developed an automatic four-circle counter diffractometer; and by A. K. Singh and Prof. S. Ramaseshan (India), who have made an integrating Weissenberg camera for use at low and high temperatures.

In the last session, Prof. J. Laval (France) gave the theory of the elastic properties of metallic crystals having cubic symmetry; Prof. R. S. Krishnan (India) discussed the infra-red and Raman spectra of glycine and related compounds in the crystalline state; Dr. S. S. Mitra (United States) gave an account of infra-red absorption in ionic erystals; and Prof. Zheludev (U.S.S.R.) spoke on the so-called anti-tensors and their symmetry, which are important in connexion with the colour groups developed by Russian crystallographs.

The symposium was attended by about 40 overseas and 150 Indian delegates, who enjoyed the organization and stimulating programme arranged by Prof. Ramachandran and his colleagues. Its success was much to the credit of one of the regrettably few university departments in the Commonwealth that are devoted to the teaching and practice of biophysics.

D. C. Phillips

\section{COMMUNICATION SATELLITE RESEARCH IN BRITAIN}

$I^{N}$ opening a debate in the House of Commons on March 25 on Post Office capital investment and tariff increases, the Postmaster-General, Mr. R. Bevins, referred briefly to satellite communications and said that, so far as could be judged, this would be the cheapest method of providing the increased capacity needed to handle the very rapid expansion in international telephoning; submarine cables and satellites would probably be supplementary systems for many years to come. Since about 80 per cent of inter-continental traffic was across the Atlantic Ocean between North America and Europe, any satellite system that was to pay must draw to some extent on trans-Atlantic traffic, and that was why the Post Office was putting much work at the political, administrative and scientific levels into the associated problems. At present, between $£ 1$ and $£ 2$ million was allocated for Post Office research as such.

The whole question of telecommunications space satellites was debated on March 29, when a motion of $\mathrm{Mr}$. Farey-Jones-asking the Government to announce plans for the provision of a British and Commonwealth telecommunications satellite and to treat the matter as one of great urgency to maintain British leadorship in communications, to prevent the dissipation of existing design staffs, and to restore confidence in the future of British scientists-was adopted. In this debate the Assistant Postmaster-General, Mr. R. Mawby, repeating Mr. Bevin's remark about the need for such a system to carry traffic from the United States, said that the British share of world inter-continental traffic was 10 per cent, and the whole traffic between Commonwealth countries only 20 per cent. Revenue from traffic originating and terminating in the United States was expected to be $75-80$ per cent of the total by 1975. Of the present 2.4 million intercontinental telephone calls a year, only 600,000 did not cross the Atlantic; by 1970 the latter figure was expected to inerease to about 3 million and to 9 million by 1980 , but this would still represent only 30 per cent of the total inter-continental traffic. It was unlikely that the revenue available to support a global system giving world-wide coverage would exceed $£ 60$ million a year by 1970 .
Britain's own investigations were directed to a system utilizing twelve stations keeping satellites in equatorial orbit, the capital cost of which might be $£ 160-190$ million and the annual cost £32-37 million. The experimental ground station built at Goonhilly Down in Cornwall had already co-operated with brilliant success in the transAtlantic tests with the American experimental telecommunications satellites Telstar and Relay and was believed to be much nearer the design of the ultimate operating station than any other in the world. Its equipment was now being improved and extended so that it would be ready as an operational station when the first system of regular commercial satellites was put into orbit. Britain was also putting in hand a design study for the communications part of the equipment which goes into a satellite and was participating in the necessary complicated pattern of international discussions. A series of exploratory discussions of the broader aspects of the question had opened with the Commonwealth Conference on Satellite Communications in London last spring, followed by preliminary discussions with the United States and Canada in Washington last October, and with European countries at Cologne in December under the ægis of the Conference of European Postal and Telecommunications Administration. An ad hoc committeo set up by this Conference to study the wider aspects of the problem had already mot in Paris, was meeting in London in June and would present a considered view to the next plenary meeting in September.

In replying on the debate, the Minister of Aviation, Mr. J. Amery, after explaining that the Ministry of Aviation would be responsible for developing and procuring launchers and satellites that other Departments might need, added that the decisions taken or about to be taken on space communications would have very farreaching implications for Britain's general position as an aero-space power. The European Launcher Development Organization launcher was planned to put a test pay-load into orbit by 1966-67 and should provide the launching capability for an operational satellite system in 1968-69. Britain was about to let contracts with industry for the design and construction of Ariel III, which would be the 